\title{
What's Wrong With the Federal Reserve: What Would Restore Independence?
}

\author{
ALLAN H. MELTZER*
}

The actual degree of independence of the Federal Reserve has varied over the years. This paper traces its history and finds that the Federal Reserve has been most successful in its dual full-employment, low inflation mandate when it follows fixed rules, and focuses on the intermediate term rather than trying to react to short-term developments under political pressure. Going forward, monetary policy should emphasize on annual monetary growth more and short-term interest rates less. A number of policies are recommended to support this overall emphasis on intermediate-term stability.

Business Economics (2013) 48, 96-103.

doi:10.1057/be.2013.7

Keywords: Federal Reserve, independence, monetary policy, monetary history, Taylor Rule

I don't suppose that anyone would still argue that the central banking system should be independent of the Government of the country. The control which such a system exercises over the volume and value of money is a right of Government and is exercised on behalf of Government, with powers delegated by the Government. But there is a distinction between independence from Government and independence from political influence in a narrower sense. The powers of the central banking system should not be a pawn of any group or faction or party, or even any particular administration, subject to political pressures and its own passing fiscal necessities. [Allan Sproul, President of the New York Federal Reserve Bank letter to Robert R. Bowie, September 1, 1948 [Meltzer 2003, p. 738]

E ew would disagree with Sproul's statement. The greater problem is not agreeing about the desirability of independence. It is finding institutional arrangements to achieve it and retain it if it is achieved.

We all learned, and many repeat, that the Federal Reserve is independent within government. That was certainly true of the Federal Reserve in 1913, but by 1917 it helped to finance the war by lending to the Treasury to finance bank purchases of war debt at concessional rates. After the war, the Treasury Secretary insisted on holding low interest rates to support refunding of government debt. ${ }^{1}$

The 1920s were better. Secretary of the Treasury, Andrew Mellon, started the decade by letting interest rates rise. Benjamin Strong, the Governor of the Federal Reserve Bank of New York, was the dominant personality strong enough to prevent the Board in Washington from gaining control of policy. However, Strong circumvented the clear prohibition against using monetary policy to finance the Treasury by actively purchasing and selling government securities in the open market. And the Board agreed to modify the prohibition against direct Treasury finance by putting a dollar limit on the amount of direct finance.

\footnotetext{
${ }^{1}$ Much of this section is based on Meltzer [2002, 2010]. Goodfriend [2012] is a current discussion of independence.
}

Material from this paper was presented at the NABE Session of the 2013 American Economic Association Meeting, "Fed Independence in the Aftermath of the Financial Crisis: Should We Be Worried?"

*Allan H. Meltzer is the Allan H. Meltzer University Professor of Political Economy at Carnegie Mellon University. His research and teaching interests include the history of U.S. monetary policy, size of government, macroeconomics, and international financial reform. He was the founder and chairman of the Shadow Open Market Committee. Meltzer has served as a consultant on economic policy for the Congress, the U.S. Treasury, the Federal Reserve, the World Bank, and the U.S. and foreign governments. He was Chairman of the International Financial Institution Advisory Commission, U.S. Congress, 1999-2000. He was given NABE's Adam Smith Award in 2003 and is a NABE Fellow. He received A.B. and M.A. degrees from Duke University and a Ph.D. from the University of California at Los Angeles. 
One strand of Federal Reserve history develops the shift in power and influence toward Washington. President Wilson's compromise made the Board in Washington an overseer of the semi-independent Reserve Banks. Wilson's compromise settled the issue long enough to get Congress to pass the Federal Reserve Act. The issue of control reemerged almost at once.

Discussion at the time described the Board of Governors as a political body, the regional banks as representing business and possibly consumers. Prohibitions to support independence included the aforementioned prohibition on direct Treasury finances, but also gold standard rules, portfolio decisions controlled by Reserve Bank directors, the real bills doctrine, and 14-year terms for Board members. Real bills restricted Federal Reserve purchases to financing commercial paper and acceptances brought at the option of members to the Reserve Banks. The main discretionary action left the banks free to set their discount rates subject to approval by the Board.

By the 1920s, Governor Strong had organized the banks into the open market committee empowered to decide on purchases and sales in the open market subject to Board oversight and portfolio approval by bank directors.

The 1920s are the high point of independence under the managed gold standard. Each financial and economic crisis thereafter shifted influence away from the Reserve Banks and their directors to the Board members and staff. Some of the restrictions in the 1913 Act are much weaker; most, but not all, are gone.

Revision of the Federal Reserve Act in 1935 gave the Board the control of open market decisions that its members had wanted for years. Regional directors no longer controlled portfolio decisions. The discount rate had been centralized earlier. In the inflationary 1970s, Congress expanded political influence by extending membership on the Reserve Bank board to a more representative group in the districts. Following the recent crisis, directors lost some of their few remaining responsibilities.

The Federal Reserve now has unrestricted power to do what it chooses. It vastly expanded its balance sheet; it engages in credit allocation; it holds down market rates on all Treasury securities, in part to recapitalize the money-center banks. It sacrifices independence by responding to pressures from Congress and the administration. It has never announced a lender-of-last-resort policy, and it continues to support too-big-to-fail policies that shift costs to taxpayers.

The Federal Reserve long ago gave up some of its independence. For five years after World War II, it maintained a 2.5 percent ceiling on long-term Treasury rates because it was unwilling to challenge members of Congress. In the 1960s and 1970s, then Chairman William McChesney Martin, Jr. said repeatedly, as in the quotation from Allan Sproul at the start, that the Federal Reserve was independent within government. He explained that Congress approved the federal budget. If it authorized deficit spending, the Federal Reserve, within government, should help to finance the Treasury's securities sales. When deficits rose in the 1960s, inflation soon followed.

Arthur Burns succeeded Martin as chairman. Burns was unwilling to pay the political cost of reducing inflation. Inflation rose during his eight-year chairmanship. When unemployment rose following each effort to control inflation, the Burns Federal Reserve increased money growth. During the 1970s, inflation and unemployment rose. The Board's staff and many others used models in which higher inflation lowered unemployment. The data for the period show the opposite over time.

Independence increased during the Volcker and Greenspan chairmanships, but decreased substantially in 2008 and after. Having shown members of Congress its ability to expand money and credit massively, it will be difficult to avoid repeating such expansions in the future.

Discretionary authority to regulate financial markets and banks has always been divided in the United States. Federal Reserve authority has grown and, with it, rule by regulators has supplanted reliance on common standards for risks and the rule-of-law. The Board of Governors has often equated the interest of New York's largest banks and the public interest. This, too, subverts independence.

Can independence be restored?

\section{The Policy Record}

One possible defense of the limits on independence might be that the Federal Reserve's policies were more successful as a result. Selgin, Lastrapes, and White [2012] cast doubt on that conclusion. Their comparison suffers from differences in the quality and content of data over two distinctly different periods, under very different political 
regimes. It seems better to conclude that a largely discretionary policy has not brought clear evidence of superior performance.

My own study of Federal Reserve history found that, in its (almost) 100 years, the Federal Reserve has rarely achieved sustained periods of relatively stable growth and low inflation. The two periods I identified were both years in which the Federal Reserve more or less followed a specific rule. In 1923-28, the Federal Reserve followed a weak type of gold standard. From about 1985-2003, the Federal Reserve closely followed John Taylor's rule [Taylor 1993]. In other nonwar years, the Federal Reserve caused the Great Depression and did very little during the subsequent slow recovery, 1929-41. Its main action contributed to the serious 1937-38 recession. During the Great Inflation, 1967-79, it produced a series of cycles that usually ended with higher inflation followed by recession and increased unemployment. This is not a distinguished record.

Regulatory policy does not improve the record. The Federal Reserve watched while banks reduced equity capital after the government approved deposit insurance. Before the most recent crisis, the Federal Reserve permitted large banks to circumvent capital regulations that would have restricted their portfolios of risky mortgages. And it sent examiners into all large banks to observe portfolio decisions, but it failed to prevent any purchases.

Earlier, the Federal Reserve discussed the problems created by interest rate ceilings on bank deposits, but it never chose to remove them. As a result, a gigantic nonbank industry rose. In the 1920s, the Federal Reserve succumbed to bank pressure by permitting national banks to invest in mortgages. And it took more than one banking crisis to rid the United States of many local or regional banks that failed in large numbers when the local industry went into recession and could not repay its borrowing.

\section{Some Reasons for the Federal Reserve's Main Mistakes}

Independence is central to the Federal Reserve's ability to choose policy actions that achieve price stability. Sacrificing much of its independence, as the Federal Reserve often has, permits others to pressure the Federal Reserve to achieve other objectives, usually short-term objectives. That is one reason that the Federal Reserve responds to short-term events often at the cost of failing to achieve longer-term objectives.

When I read Federal Reserve minutes or transcripts from the mid-1920s through 1986, I was struck by the almost complete absence of policy discussions that asked: If we take this action today, what do we expect to happen one or two years from now? It is true that, for many years, the Board staff and several Reserve Bank staff gave forecasts for several years ahead. Less clear is the effect that these forecasts have on policy action. The choice of policy action, during the postwar years in my history, is usually a decision about whether the funds rate should change by $1 / 4$ percent or remain unchanged.

In interpreting changes in economic data, a frequent problem is distinguishing temporary from permanent changes in levels but also in growth rates. Alan Greenspan's recognition of the 1990s increased productivity growth is now legendary. Most of his colleagues and the staff did not agree, and it was only through Greenspan's leadership and conviction that the Federal Reserve responded appropriately to a persistent change. The other main example is Paul Volcker's pursuit of lower inflation from 1979 to 1982 . Volcker understood that he had to achieve a permanent change and that, doing so, would require sustained commitment to put the economy permanently on a different path.

One example of the Federal Reserve's shortterm focus is the series of actions called QE2 in the summer of 2010. Day traders claimed that the economy was headed toward even slower growth, recession, and deflation. The Federal Reserve announced $\$ 600$ billion of purchases to be achieved over subsequent months. Within a few months, it was clear that the summer slowdown was a transitory change that reversed before the purchases started.

At the time, the Federal Reserve's balance sheet had hundreds of billions of excess reserves. What could QE2 do to encourage expansion that banks could not do by using excess reserves to expand money and credit? By far the larger part of the addition to reserves under QE2; $\$ 500$ of $\$ 600$ billion ended as additional excess reserves. Most of the rest ended in foreign central bank portfolios as part of their effort to prevent additional currency appreciation. The modest gain to the U.S. economy from QE2 came from dollar devaluation. The day traders and speculators benefitted from the temporary decline in U.S. 
interest rates. I know of no evidence that the brief fall in long-term rates increased purchases of housing and durables.

QE2 was a mistake. The main error was to interpret a short-lived decline in activity as a persistent change. Anyone familiar with data on real GDP or other measures of economic activity knows very well that quarterly real GDP growth rates are highly variable and difficult to forecast accurately. It is impossible to infer whether a change is persistent from data on a month or quarter. It is clear that the market acts as if the Federal Reserve responds to transitory changes. Is there any evidence showing that additions to reserves at this time will generate enough economic expansion to raise the growth rate? Treasury interest rates are at historic low values. More than \$1.5 trillion of excess reserves sit idle on bank balance sheets. Why would a few hundred billion more have a persistent response? What evidence suggests that current problems are monetary rather than real? We are not in a liquidity trap: current economic problems are not monetary.

Excessive concern for short-term changes causes the Federal Reserve to respond to events over which it has little control and largely ignore longer-term changes that it can influence [Brunner Cukierman and Meltzer, 1980]. One can appreciate the political and market pressures that Federal Reserve policymakers, especially the chairman, face. That is the reason for independence, but it requires determination to resist the pressures. The Federal Reserve recognized the need to resist political pressures when it agreed on an inflation target in January 2012. Will it do it? We can see the same pressure at work in Europe where the ECB has violated or circumvented many of the restrictions in its charter. But we need not look only at Europe.

Another source of repeated error is reliance on the Phillips curve. The original Phillips curve relies on data that comes mainly from the gold standard years, which restricted changes in expected inflation. Scores of studies of the Phillips curve conclude that its main weaknesses come from changes in expected inflation and sustained output growth. Phillips curves assume that sustained output growth is given. Evidence rejects this assumption.

Work at the Board by Orphanides [2002 and elsewhere] showed that the staff's forecasts of inflation were inaccurate and biased downward. His studies also showed that the principal problem was that expected output could not be measured accurately.
Both Chairman Volcker and Greenspan told the staff that their forecasts of inflation were not useful. Volcker pointed out publicly that, contrary to the Philips curve trade-off, unemployment and inflation had increased together during the 1970s. He said he expected the unemployment rate to decline with inflation in the 1980s. He was right. A long period of low inflation, relatively stable growth; short, mild recessions; and relatively low unemployment rates followed.

Chairman Volcker made some significant changes in economic policy. First, he sustained an anti-inflation policy as unemployment rose. At first, markets were skeptical that he would maintain his stance after interest rates and unemployment rose and a deep recession began. Markets expected policy to reverse course. Instead, with unemployment at 8 percent in spring 1981, the Federal Reserve raised the funds rate. That had never happened before. Within 15 months, inflation fell below 5 percent for the first time in years. The unemployment rate declined subsequently.

The first lesson is that sustained policy actions are necessary to achieve the long-term objectives of stable growth and low inflation. A second lesson is that recovery occurred, despite the real long-term interest rates of 7 percent from 1982 to 1985. Discussion in the FOMC minutes at the time expressed uncertainty about whether the response to money growth would dominate relatively high real interest rates. It did.

Third, Paul Volcker spoke frequently to Congress and the public to teach the anti-Phillips curve messages. His message was that low inflation was the best way to achieve stable growth and low inflation. This message requires policy actions to focus on the medium-term. By the late 1980s, many members of the Congressional banking committees accepted that idea. Unfortunately, the Board staff and much of the current FOMC membership continues trying to do the opposite, reduce unemployment by expanding and inflating.

In practice, the Phillips curve has another large problem as used by the Federal Reserve. In the 1970s, several FOMC members made strong commitments to reduce inflation as it rose. Each effort ended when the unemployment rate rose to about 7 percent. Policy shifted to reducing the unemployment rate. Expected inflation rose. Markets waited to see whether anti-inflation policy would persist. When it did not, inflation expectations became firm. Any temporary reduction in inflation was not expected to last; inflation was 
expected to move higher. It did, and therefore statements in later years had little effect.

Congress gave the Federal Reserve a dual mandate in the 1970s. The Federal Reserve was charged with keeping both unemployment and inflation rates low, a task that it achieved from 1985 to about 2003, but at no other extended period in the postwar period. One reason it fails is that it concentrates on one of the two objectives at a time. This is inefficient and increases variability. (A possible exception is the mid-1950s, 1953-56, when budget surpluses were common.)

When unemployment rises, the Federal Reserve lowers interest rates and delays increases until inflation rises. After some time, policy raises interest rates to slow the economy and lower inflation. Markets have learned that the Federal Reserve will not persist in anti-inflation policy after inflation rises, and thus they wait for the policy reversal.

Taylor $[1979,1994]$ shows the tradeoff between variability of inflation and variability of output. By shifting from an unemployment goal to an inflation target and back again, the Federal Reserve increases variability, and in the past did not achieve either goal. Its performance improved when it more or less followed a Taylor rule that emphasized both goals simultaneously.

In recent years, Federal Reserve staff and some principals analyze events using an elegant model developed in a study by Woodford [2003] and subsequent papers. The model has an explicit micro foundation. It combines a Phillips-type aggregate supply equation with rational expectations based on aggregate demand to solve for inflation and output. The central bank sets the only interest rate. All other nominal interest rates and asset prices are assumed to follow from the single rate and expected inflation.

Despite its elegance, this model should not be taken as a serious model of monetary policy. It lacks highly relevant parts of the monetary transmission mechanism. There is no central bank balance sheet, no money, no credit variables, and no prices of any real asset. One can use the demand for money to compute the consistent quantity of money, but money has no bearing on any real or nominal value. In Woodford's model, market participants talk about how asset price bubbles must be treated as wholly a result of expectational changes. Are such changes always rational? Can they be financed without a shift in portfolios from money to the particular real asset that speculators choose? Didn't the Federal Reserve policy of keeping the interest rate from rising in 2003 and part of 2004 permit lenders to finance mortgage purchases on favorable terms? Wasn't the same type of credit and monetary expansion at work in the so-called dot-com speculations in the late 1990 s? ${ }^{2}$

Much earlier, long tradition treats central banks as suppliers of money and credit and treats monetary changes as affecting asset prices. Friedman's [1956] paper on the quantity theory includes representative prices of stock and flow variables as relevant for the demand for money and, by inference, aggregate credit and labor demand. Relative prices of assets and output affect these demands and the transmission of monetary policy [Meltzer 1995].

In the 1960s and 1970s, separately, James Tobin [1969] and Karl Brunner and I [1993] developed general equilibrium models that included asset and credit or money markets. These models did not restrict transmission of monetary impulses or interest rate changes solely to expectations. ${ }^{3}$ Relative prices of assets and output have a central role. In long-run adjustment, the term structure of interest rates settles at the value of expected future short rates, as in the study by Woodford [2003] and much other work. Taylor [1995] includes several relative prices in his empirical work. As Alan Blinder [2004] concluded after his service on the Board of Governors, all available evidence rejects the shortrun expectations theory of the term structure.

The Woodford model's concentration on the single short-term rate, controlled by policy actions, reinforces the political pressures to respond to current events and improve longer-term consequences of today's actions. It is not implied by the model, but the model wraps all future responses into rational expectations. The large cost of acquiring information about future asset and labor market prices is neglected [Brunner and Meltzer 1993].

An alternative approach developed at the Bundesbank and the European Central Bank [Issing 2005, 2012 and elsewhere] used a money growth measure to gauge the degree to which short-term operations remained consistent with low inflation. This relatively successful policy of maintaining low inflation incorporated both traditional

\footnotetext{
${ }^{2}$ Woodford [2012] incorporates some of the variables previously neglected. But the changes minimize the influence of money and credit variables. Woodford's policy analysis contrasts with the successful policy maintained by Issing [2012].

${ }^{3}$ Goodfriend and McCallum [2007] have a recent model with money and credit.
} 
money market variables and longer-term implications of the policy actions.

Could Issing's approach work in the United States? The Federal Reserve rejects use of any monetary aggregate by claiming that monetary velocity is unstable. This conclusion comes from tests based on quarterly data. This is another example of the dominant role of myopia. Issing's procedure, wisely, did not rely on quarterly data. I have noted before that annual values of the velocity relation show reasonable stability. Two especially noteworthy features are the return of base velocity in the 1960s to the same range of values found for the 1920s when the interest rate returned to the 1920s region after 40 years. In addition, base velocity rose from about 7 to more than 14 during the Great Inflation of the 1970s. It then declined along the same path during the 1980s' disinflation. These results strongly support Issing's procedure for the United States. The Federal Reserve's record at controlling inflation would be improved, and it would be induced to think about the medium- and longer-term consequences of its market actions if it paid more attention to annual velocity.

\section{What Would Be Better?}

Part of the answer to the question about how to improve policy is implicit in the previous sections. The Federal Reserve should commit to a rule, or quasi-rule such as the Taylor rule that aims at both reduced unemployment (or relatively stable output growth) and expected inflation. The rule incorporates the dual mandate that Congress approved and that the public seems willing to support. When the Federal Reserve followed it closely, it worked well.

The Federal Reserve should use models that include credit, money, and assets. The central problem of stability requires that policy acts in a way that induces the public to hold money, bonds, and real capital at equilibrium values consistent with stable output growth and low inflation.

Adopting a rule is a first step. The next step is to strengthen incentives to follow the rule. The Federal Reserve has much more authority than accountability. Neither Governor Harrison nor the Federal Reserve Board were fired for causing the Great Depression, but President Hoover, Secretary Mellon, and many members of Congress lost their positions. Arthur Burns and the Board of Governors were not fired, but President Carter and members of Congress were.
To increase accountability, the Federal Reserve should announce an objective, the combination of inflation and unemployment rate or output growth rate that it expects to achieve over several years, most likely 2 or 3 . If it fails to achieve its objective, it must offer an explanation and submit resignations. The president can accept the explanation or the resignations. Several countries, starting with New Zealand, have adopted this arrangement. It has not produced resignations, to my knowledge, but it has enhanced incentives to concentrate on medium-term objectives.

A peculiarity of the emphasis given to current and near-term events is that monetary policy operates with a lag. Policy actions today cannot do much about output, employment, or inflation in the near-term. No less important is that intense pressures to do something about current problems often neglect current actions that make it more difficult to resolve long-term problems. Some current examples: How can the Federal Reserve reduce the $\$ 1.5$ trillion of excess reserves without increasing inflation and/or unemployment? Adding to excess reserves to respond to a current economic slowdown exacerbates the problem. Some propose higher inflation as a way of reducing unemployment and the value of our enormous debt. This again presumes a persistent trade-off, contrary to 1970s and 1980s experiences.

Excessive attention to short-term changes neglects the distinction between permanent and temporary changes that is central to standard economic analysis. Several examples of recent neglect of this distinction are available:

- The claim of slowing growth in the summer of 2010 was the beginning of deflation and a return of recession. By early autumn, these forecasts and conjectures proved incorrect. The Federal Reserve eased. Most of the additional reserves added to excess reserves.

- In the exceptionally warm winter of 2012 , U.S. economic growth rose. There was no way to know for months whether the improvement was a temporary response to mild winter or a persistent improvement.

- Orphanides and Williams [2011] reported that 2006 was a year of wasted resources in the ECB. Data revisions in 2009 reversed that conclusion.

- Issing [2012] quotes Gordon Brown's reasons for restoring independence to the Bank of England. "The previous arrangements for monetary policy were too short-termist, encouraging 
short but unsustainable booms and higher inflation, followed inevitably by recession."

These examples can be extended almost endlessly.

A common response to my concern about future inflation is that future inflation is not a problem because the Federal Reserve can always raise its interest rate enough to slow inflation. In principle, this is certainly true. But practice, I fear, is different. Business, labor, and members of Congress are not indifferent about the level of interest rates. When the 1921 Board allowed rates to rise above 6 percent, Congress discussed curtailing its authority. I claim in my history that was a major reason why the Board resisted raising the discount rate in 1928-29 before the depression. Secretary Morgenthau in the 1930s was often alarmed and threatening if interest rates rose by even small amounts. After World War II, the Federal Reserve would not end wartime-pegged long rates until it gained the support of some influential members of Congress, especially Senator Paul Douglas. And more than 30 members of the Senate sponsored legislation in summer 1982 to force Paul Volcker's FOMC to reduce interest rates.

The Federal Reserve has reason to be concerned about Congressional intervention. Legislative threats are common. Between 1973 and 2010, members of Congress introduced 1,575 bills in the House and 728 bills in the Senate. About 75 percent die without further action [Hess and Shelton 2012]. No one knows whether one will gather support.

In its first 100 years, the Federal Reserve has never announced a lender-of-last-resort policy. Every banking crisis brings some actions, but there is never an announced rule, Bagehot's [1873] famous criticism of the Bank of England's policy did not fault its actions. Bagehot' s criticism was that the Bank did not announce its policy in advance.

That same criticism applies to the Federal Reserve. By announcing and following its policy, the Federal Reserve would notify banks about what it will and will not do. It gives them an incentive to hold collateral acceptable for discount at the Reserve Banks. It reduces uncertainty, surely a gain during crises. It also reduces the expected gain from failing banks asking Congress to press the Federal Reserve or others for bailouts. And if banks follow the rule by holding collateral and equity reserves, fewer fail.

A policy rule for too-big-to-fail should not be the main way to prevent failures. Far more important is a rule that prevents most failures.
Congress should enact equity capital standards for banks. I propose that beyond some minimum size, equity capital requirements should increase with asset size up to a maximum of 20 percent of assets. Losses would be borne by stockholders. The Federal Reserve and other regulators would monitor capital requirements. Outside auditors would certify that the requirements are met.

Rising proportional requirements avoid judgments about risk of particular assets that can be used to circumvent requirements. Proportional requirements induce management to avoid excessive risk. If a major bank takes excessive risk, astute stockholders sell to avoid possible loss of value. That alerts others.

Equity reserves should replace much regulation of asset portfolios. We learned that in the period well before the mortgage and financial market collapse that hundreds of federal regulators observed portfolio decisions at all the major banks without opposing any. Banks evaded risk-based capital requirements by putting risky assets in separate entities. Regulators permitted the evasion. There are many additional examples of forbearance and evasion.

One further recommendation applies to money market funds. They exist only because the Federal Reserve and Congress maintained ceiling rates for bank time deposits during years of rising inflation. These are mutual funds that have a special privilege. When prices of their asset portfolio would require them to pay less than one dollar per dollar of nominal deposits, they do not mark deposits to market. They use the dollar price. This rule is inconsistent with the mark to market requirement of all other mutual funds. It should be repealed.

\section{Conclusion}

My criticism of the elegant Woodford models and much work that builds on them should not be read as rejection of rational expectations, dynamic macroeconomics, and the many improvements to make macroeconomic policy more credible, more predictable, and forward looking. It is not. My main criticisms are the pressures for short-term changes, neglect or medium- and longer-term effects, and reliance on the Phillips curve to forecast inflation. But it is also a criticism of the failure to follow a rulebased systematic policy for money and interest rates and for its role as lender-of-last-resort.

The two periods in which the Federal Reserve followed a rule, 1923-28 and 1983-2003, are the 
only long periods in Federal Reserve history with relatively stable growth, small recessions, and low inflation. Unpleasant experience followed both periods - the Great Depression started in 1929 and a major, deep, long-lasting recession started in 2007. I do not believe that stability was the cause of the subsequent collapse, but careful analyses of both policy failures and private expectations and attitudes toward risk is called for.

The Federal Reserve errs in ignoring money, credit, and asset prices. Its reasoning about money is based on quarterly data. Annual data show a relatively stable relation between velocity and an interest rate that includes inflation expectations.

Why is money growth relevant? It summarizes changes in asset prices that are highly relevant for policy transmission. No single asset price can capture the relative price process, but most changes require use of money substitution of real assets for money in portfolios or the reverse. These substitutions should not be ignored.

Larry Summers is known for saying that the crisis inherited at the start of the Obama administration in 2009 called for actions that were "timely, targeted, and temporary." That was very bad advice, and it failed. We have long-term problems. They call for just the opposite actions-persistent and market and incentive oriented.

\section{Acknowledgments}

Helpful comments from Marvin Goodfriend, Bennett McCallum, and John Taylor improved an earlier draft.

\section{REFERENCES}

Bagehot, Walter. 1873/1962. Lombard Street. Richard D. Irwin.

Blinder, Alan. 2004. Central Banking in Theory and Practice. MIT Press.

Brunner, Karl, Alex Cukierman, and Allan H. Meltzer. 1980. "Stagflation, Persistent Unemployment, and the Permanence of Economic Shocks." Journal of Monetary Economics, 6(October): 467-92.

Brunner, Karl, and Allan H. Meltzer. 1993. Money and the Economy: Issues in Monetary Analysis. Cambridge University Press for the Raffaele Mattioli Foundation.

Friedman, Milton, ed. 1956. Studies in the Quantity Theory of Money. University of Chicago Press.

Goodfriend, Marvin. 2012. "The Elusive Promise of Independent Central Banking," (unpublished). Institute for Monetary and Economic Studies, Bank of Japan.
Goodfriend, Marvin, and Bennett McCallum. 2007. "Banking and Interest Rates in Monetary Policy Analysis: A Quantitative Explanation." Journal of Monetary Economics, 54(5): 1480-507.

Hess, Gregory, and Cameron Shelton. 2012. Congress and the Federal Reserve. Claremont McKenna College, (xeroxed).

Issing, Otmar. 2005. "Why Did the Great Inflation Not Happen in Germany?" Review, Federal Reserve Bank of St. Louis, 87(March-April): 329-35.

2012. Central Banks-Paradise Lost. The Mayekawa Lecture, Bank of Japan (xeroxed).

Meltzer, Allan H. 1995. "Monetary, Credit and (Other) Transmission Processes." Journal of Economic Perspectives, 9(4): 49-72.

2002. A History of the Federal Reserve, 1913-1951, Vol. 1. Chicago University Press.

2003. A History of the Federal Reserve, 1913-1951, Vol. 1. Chicago University Press.

2010. A History of the Federal Reserve, Vol. 2, Book 1 (1951-1969) and Book 2 (1970-1866). University of Chicago Press.

Orphanides, Anastasios. 2002. "Monetary Policy Rules and the Great Inflation." American Economic Review, 92(May): 115-20.

Orphanides, A., and J.C. Williams. 2011. "Monetary Policy Mistakes and the Evolution of Inflation Expectations," NBER Working Papers, National Bureau of Economic Research.

Selgin, George, William Lastrapes, and Lawrence $\mathrm{H}$. White. 2012. "Has the Fed Been a Failure?" Journal of Macroeconomics, 34(3): 569-96.

Taylor, John B. 1979. "Estimation and Control of a Macroeconomic Model with Rational Expectations." Econometrica, 47(5): 1267-86.

1993. "Discretion versus Policy Rules in Practice." Carnegie-Rochester Conference on Public Policy, 39(December): 195-214.

1994. "The Inflation/Output Variability TradeOff Revisited," in Goals, Guidelines, and Constraints Facing Policymakers, edited by J.C. Fuhrer. Federal Reserve Bank of Boston.

1995. "The Monetary Transmission Mechanism: An Empirical Framework." Journal of Economic Perspectives, 9(4): 11-26.

Tobin, James. 1969. "A General Equilibrium Approach to Monetary Theory." Journal of Money, Credit and Banking, 1(1): 15-29.

Woodford, Michael. 2003. Interest and Prices: Foundation of a Theory of Monetary Policy. Princeton University Press.

2012. "Inflation Targeting and Financial Stability," NBER Working Paper 17967, National Bureau of Economic Research. 